\title{
Adoption Behaviour of ELS cotton growers in Vellore district of Tamil Nadu
}

\author{
M. Deepika ${ }^{1}$, M. Asokhan ${ }^{2}$ and S. Usha Rani ${ }^{3}$
}

\begin{abstract}
The present study was taken up to analyse the adoption behaviour of ELS cotton growers in Vellore district of Tamil Nadu. The study was taken up in two blocks of Vellore district namely, Tirupattur and Kandhili blocks. The data were collected from 132 cotton growers using a well structured interview schedule and analysed.The study revealed that less than two- thirds of the respondents had medium level of adoption followed by high and low levels.
\end{abstract}

Keywords : Cotton technologies; Cotton growers; Adoption; Tamil Nadu

Cotton is considered as "white gold" among the cultivated crops on account of its importance in agricultural and industrial sectors. Cotton occupies a prominent position in Indian economy. It is the primary raw material for the huge domestic textile industry and makes substantial contribution to the country's foreign exchange earnings.

The term 'Extra Long Staple' (ELS) cotton typically denotes a cotton fibre of extraordinary fibre length. The recognized industry standard for the minimum fibre length of an ELS fibre is $34.925 \mathrm{~mm}$. This minimum length is significantly longer than traditional varieties of cotton, known as upland cottons, where the average staple length is $26-27 \mathrm{~mm}$. Along with its fibre length, ELS cottons are also recognized for their superior strength and better uniformity.

However, even with all the benefits of the ELS fibre characteristics and its apparent desirability, it is grown only in limited area. ELS and LS (Long Staple) cottons represent only about 3.00 per cent of the entire world's cotton production. The ELS cotton varieties are specific in their needs to produce a successful crop. A proper crop management is required for ELS cottons, above that of Upland cottons. ELS cottons are vigorous growing plants and if not managed properly may grow to be large plants with minimal fibre production. Also, the relative yield of ELS cottons was less when compared to Upland cotton. Environmental conditions for ELS cottons are specific, and can be grown only in the areas having hot days and cool nights. All of these factors rest in increased production costs, with increased risks compared to upland cotton. This in turn is a major limiting factor for the production of ELS cotton.

1 PG. Scholar \& 2 Professor and Head Department of Agricultural Extension and Rural Sociology, Tamil Nadu Agricultural University, Coimbatore- 641003 and 3. Principal Scientist, ICAR-CICR Regional Station, Coimbatore-641 003

Received : 27-04-2018; Accepted : 02-07-2018 
With this background, the present study was taken up to assess the adoption behaviour of cotton growers.

\section{METHODOLOGY}

The study was conducted in two blocks of Vellore district i.e., Tirupattur and Kandhili blocks. Four villages from the two blocks were selected namely-Madapalli, Poongulam, Udayamputhur and Sevvathur with the selected sample size of 132 farmers. The data were collected using a well structured interview schedule and analysed using appropriate statistical analysis.

\section{FINDINGS AND DISCUSSION}

\section{Adoption level of ELS cotton cultivation technologies}

Adoption of innovation is perceived to be the success of extension workers. Rogers and Shoemaker (1971) defined adoption as a decision to make full use of new ideas as best course of action available. Those who had modified the recommendation and adopted were not considered for interpretation of results. The information regarding adoption of cultivation practices on cotton cultivation are presented in Table 1.

Table 1.

Distribution of Respondents based on the Adoption behaviour of Cotton

\begin{tabular}{|c|c|c|c|}
\hline $\begin{array}{l}\text { Sl. } \\
\text { No }\end{array}$ & Critical Technologies & $\begin{array}{l}\text { Adopted } \\
\text { (\%) }\end{array}$ & $\begin{array}{c}\text { Not } \\
\text { adopted(\%) }\end{array}$ \\
\hline 1 & \multicolumn{3}{|l|}{ Land preparation } \\
\hline 1 & Removing and burning debris of previous crop & 5.30 & 76.50 \\
\hline 2 & Summer ploughings twice & 77.30 & 0.00 \\
\hline 3 & Repeated harrowing & 18.20 & 39.40 \\
\hline II & \multicolumn{3}{|l|}{ Suitable ELS Bt Cotton Hybrids } \\
\hline 4 & Kesinath & 10.60 & 89.40 \\
\hline 5 & KisanJothi & 7.60 & 92.40 \\
\hline 6 & MAHYCO 6918 & 40.20 & 40.20 \\
\hline 7 & Ankur 2110 & 18.90 & 81.10 \\
\hline III & \multicolumn{3}{|l|}{ Application of Manures and Fertilizers } \\
\hline 8 & $\begin{array}{l}\text { Application of organic manure (12.5 tonnes/ ha of } \\
\text { FYM) }\end{array}$ & 5.30 & 0.00 \\
\hline 9 & $1^{\text {st }}$ top dressing of $\mathrm{NPK}(33 \%$ of $\mathrm{N}$ on $45 \mathrm{DAS})$ & 0.00 & 22.00 \\
\hline 10 & $2^{\text {nd }}$ top dressing of NPK ( $33 \%$ of $N$ on 60 DAS) & 4.54 & 22.72 \\
\hline 11 & $\begin{array}{l}\text { Application of micronutrients (Mixing of } 12.5 \mathrm{~kg} \text { of } \\
\text { micronutrient) }\end{array}$ & 23.50 & 3.80 \\
\hline 12 & Foliar spray of $3 \%$ DAP & 37.10 & 21.20 \\
\hline
\end{tabular}


Adoption Behaviour of ELS cotton growers in Vellore district of Tamil Nadu

\begin{tabular}{|c|c|c|c|}
\hline $\begin{array}{l}\text { Sl. } \\
\text { No }\end{array}$ & Critical Technologies & $\begin{array}{l}\text { Adopted } \\
\text { (\%) }\end{array}$ & $\begin{array}{c}\text { Not } \\
\text { adopted(\%) }\end{array}$ \\
\hline 13 & $\begin{array}{l}\text { Foliar spray of growth regulators ( } 40 \text { ppm NAA at } 60 \\
\text { and } 90 \text { DAS ) }\end{array}$ & 4.50 & 84.10 \\
\hline 14 & $\begin{array}{l}\text { Arresting terminal growth } \\
\text { Varieties ( for less than } 160 \text { days duration nip the terminal } \\
\text { portion of the main stem beyond } 15^{\text {th }} \text { node on } 75 \text { to } 80 \\
\text { DAS) } \\
\text { Hybrids (for more than } 160 \text { days duration beyond the } 20^{\text {th }} \\
\text { node on } 80-85 \text { DAS) }\end{array}$ & 95.50 & 0.80 \\
\hline IV & Spacing & & \\
\hline 15 & Recommended spacing $(120 * 60 \mathrm{~cm})$ & 48.50 & 1.50 \\
\hline $\mathrm{V}$ & Planting methods & & \\
\hline 16 & $\begin{array}{l}\text { Seed rate and Planting one seed/hill }(2.5 \mathrm{~kg} / \mathrm{ha} \text { with } \\
\text { fuzz) }\end{array}$ & 94.70 & 4.50 \\
\hline 17 & Planting under ridges and furrows system & 86.40 & 12.10 \\
\hline 18 & $\begin{array}{l}\text { Planting five rows per acre of non-Bt cotton seeds as } \\
\text { refugee crop surrounding the Bt cotton plot }\end{array}$ & 13.60 & 86.40 \\
\hline 19 & Planting seeds @4-5 cm deep \& covering with soil & 81.10 & 17.40 \\
\hline 20 & $\begin{array}{l}\text { Gap filling in the Bt and non - Bt areas a week after } \\
\text { germination }\end{array}$ & 6.80 & 93.20 \\
\hline $\mathrm{VI}$ & Inter cultivation and weed management & & \\
\hline 21 & $\begin{array}{l}\text { Pre-emergence application of weedicide } \\
\text { (Pendimethalin @ 3.31/ha 3DAS) }\end{array}$ & 15.20 & 84.80 \\
\hline 22 & Hand weeding (45 DAS) & 95.50 & 1.50 \\
\hline VII & Irrigation management & & \\
\hline 23 & During germination & 94.70 & 0.80 \\
\hline 24 & During seedling growth & 80.30 & 0.80 \\
\hline 25 & During flowering & 75.00 & 0.80 \\
\hline VIII & Disease management & & \\
\hline 26 & Field sanitation & 90.90 & 3.80 \\
\hline 27 & Soil drenching & 6.80 & 84.80 \\
\hline 28 & Application of fungicides & 21.20 & 5.30 \\
\hline
\end{tabular}




\begin{tabular}{|c|c|c|c|}
\hline $\begin{array}{l}\text { Sl. } \\
\text { No }\end{array}$ & Critical Technologies & $\begin{array}{l}\text { Adopted } \\
\text { (\%) }\end{array}$ & $\begin{array}{l}\text { Not } \\
\text { adopted(\%) }\end{array}$ \\
\hline IX & \multicolumn{3}{|l|}{ Pest management } \\
\hline 29 & Crop Rotation & 62.90 & 9.10 \\
\hline 30 & Summer ploughing and field sanitation & 24.20 & 7.60 \\
\hline 31 & Intercropping & 86.40 & 9.10 \\
\hline 32 & Trap cropping & 2.30 & 97.00 \\
\hline 33 & Use of bio- control agents & 9.80 & 84.10 \\
\hline 34 & Pheromone spray & 17.40 & 80.30 \\
\hline 35 & Botanical insecticides & 34.10 & 37.10 \\
\hline 36 & Mechanical control & 29.50 & 26.50 \\
\hline 37 & Chemical control & 36.40 & 23.50 \\
\hline $\mathrm{X}$ & \multicolumn{3}{|l|}{ Harvesting } \\
\hline 38 & $\begin{array}{l}\text { Harvesting at frequent intervals (less than } 7 \text { days of } \\
\text { interval) }\end{array}$ & 62.90 & 1.50 \\
\hline 39 & Harvesting in the morning hours upto $10-11$ AM & 30.30 & 43.90 \\
\hline 40 & Picking kapas from well burst bolls & 96.92 & 0.00 \\
\hline 41 & Removing only the kapas not the bracts & 98.50 & 0.00 \\
\hline 42 & $\begin{array}{l}\text { Separating the stained, discoloured and insect damaged } \\
\text { kapas from good kapas }\end{array}$ & 95.50 & 0.00 \\
\hline $\mathrm{XI}$ & \multicolumn{3}{|l|}{ Post harvest techniques } \\
\hline 43 & Shade drying the kapas & 93.90 & 86.40 \\
\hline 44 & Grading the kapas & 93.20 & 0.00 \\
\hline 45 & Drying over dry sand & 0.80 & 0.00 \\
\hline
\end{tabular}

Table 1 reveals that with respect to adoption of technologies in cotton more than threefourths $(77.30 \%)$ of the respondents adopted summer ploughing for land preparation followed by repeated harrowing (18.20\%) and removing and burning debris of previous crops (5.30\%).

The cotton growers before sowing the cotton seeds, ploughed the field across the slope during hot summer so that the hard crusted upper layer of the soil broken and it improved the soil structure. Deep ploughing and over turning uprooted the weeds as a result, the weed control and less application of weedicide is one of the major advantages of summer ploughing.

It could be seen from Table 1 that about two-fifths $(40.20 \%)$ of the respondents were adopting MAHYCO 6918 hybrid seed technology followed by Ankur 2110 (18.90\%), Kesinath (10.60\%) and KisanJothi (7.60\%). 
The possible reason might be that MAHYCO 6918 is suited to the dry land and it had long duration potential of 108 to 200 days. This sturdy plant with high boll retention capacity grows as a tall spreading plant type. The extra long staple 35.0 to $35.5 \mathrm{~mm}$ bears fluffy boll opening and remains green up to harvest. Due to the absence of dealership of hybrids like KisanJothi, Kesinath, the farmers resort to use these hybrids.

Regarding the planting methods, majority of the farmers had adopted the technologies as recommended for the following sub items- seed rate, planting under ridges and furrow, planting seeds at $4-5 \mathrm{~cm}$ deep with 94.70 per cent, 86.40 per cent, and 81.10 per cent respectively. Most (86.40\%) of the respondents had not adopted the technology of sowing non Bt seeds as refuge crop and 93.20 per cent of the respondents had not adopted the technology of gap filling.

With respect to inter cultivation and weed management, majority $(84.80 \%)$ of the respondents had not adopted the technology of application of herbicide and 95.50 per cent of the respondents adopted hand weeding as they found hand weeding more suitable for this operation.

Regarding irrigation management, majority of the respondents followed the recommended irrigation management practices like irrigating during germination, seedling growth and flowering with 94.70 per cent, 80.30 per cent and 75.00 per cent respectively.

Regarding pest management, it could be inferred that nearly two-thirds (62.90\%) of the respondents had adopted crop rotation and 86.40 per cent of the respondents were practicing intercropping as red gram for their additional income. Majority of the farmers had not adopted the recommended technologies like trap cropping, application of bio control agents, application of pheromone spray and botanical insecticide with 97.00 per cent, 84.10 per cent, 80.30 per cent and 37.10 per cent respectively.

Majority of the farmers did not adopt the practice of conservation of predators, parasitic wasps and introduction of bio control agents in the field. The farmers lacked technical skill in handling and using them in conservation of natural enemies. Moreover, the farmers might not have been convinced about this practice due to slow impact on the control of pests. The farmers might have felt that the adoption of above technologies might affect their net income and this could be the possible reason for the non adoption of the technologies.

From Table 1, it could be seen that majority of the farmers adopted the following technologies like harvesting at frequent interval, picking kapas, removing only the kapas not the bracts, separating the stained kapas from good kapas with 62.90 per cent, 96.92 per cent, 98.50 per cent and 95.50 per cent respectively. More than two-fifths (43.90\%) of the respondents had not adopted the technology of harvesting as recommended due to the labour demand and unsuitable time.

With respect to post harvest techniques, majority of the respondents 
had adopted the shade drying and grading techniques as recommended with 93.90 per cent and 93.20 per cent respectively.

It may be concluded from the study that since the respondents had medium level of adoption of recommended technologies there is an imperative need to raise the level of adoption. The extension officials could go for location specific reinvention of specific cotton technologies which improve the farmers' understand ability on complex technologies.

The study also indicated that fertilizers and pests management technologies must be popularised more through more number of meetings, demonstrations, field visits so that farmers can gain more knowledge on those and adopt the technologies accordingly.

\section{REFERENCES}

Savitha,V., Jakesh, K., Deep, P., \& Rashmi. (2014). Adoption and impact assessment of conservation agriculture technologies with special reference to growing of cotton crop with drip irrigation. Journal of cotton research and development. 28(1),154-160

Shilpa, C.N., \& Nanjappa, D. (2014). Knowledge and adoption behaviour of potato growers in Hassan district of Karnataka, Journal of Extension Education, 26(1), 5179-5185.

Sudhakar, B., \& Muthukumaran, N. (2014). Identifying the adoption level of IPM oriented cotton growers in an irrigated condition - An overview analysis, EPRA International Journal of Economic and Business review, 2(1).

UshaRani, S., \& Selvaraj, G. (2015). Adoption behaviour of $B t$ cotton growers in irrigated and rainfed conditions of Tamil Nadu Journal of cotton research and development. 29(1), 132-140.

http://www.nfsm.gov.in/StatusPaper/ CottonStatus2017.pdf 